\title{
Proposed M-learning Model based on Two Models (Technology Acceptance Model and DeLone and McLean IS success Model)
}

\author{
Ammar Khader Mohammad Almasri \\ Albalqa Applied University \\ Amman \\ Jordan
}

\begin{abstract}
This paper presents findings from an ongoing cross-cultural study exploring the implementation of M-learning environments in higher education in Jordan. The aim of the study was to explore factors affecting students' acceptance and use of M-learning. A questionnaire was developed based on the Technology Acceptance Model and DeLone and McLean IS success model. Data was collected from different master students in public and private universities in Jordan. The findings of the study suggest that Information Quality by students in regard to mobile learning as the most important antecedent to their Intention and Attitude To Use of mobile technologies for learning.
\end{abstract}

\section{Keywords}

IS success model, Information Quality, TAM

\section{INTRODUCTION}

E-Learning is using electronic media information and communication technologies (ICT) in education [1]; Such as, Computer Based Instruction (CBI), Computer-Based Training (CBT),Internet-Based Training (IBT),Web-Based Training (WBT), online education, and M-learning. Many definitions of E-Learning are related to the type of learning that is falling in and what is being learned from definitions that concentrate on the role of technology and infrastructure [2].

According to [3] the learner faces difficulty while accessing material through using a personal computer that related to the place or location. Mobile technologies have enabled a new way of communicating and learning [4] as well as have the power to make learning even more widely available and accessible anywhere and anytime; than we are used to in existing e-learning environments. Furthermore mobile phones will play the vital role to improving the educational processes; and changed the way of teaching and learning processes [57]. Also can be considered as one of the cheapest tool which can be used for learning $[7,8]$.

Despite of availability of using mobile and wireless technologies in learning since few years, the researchers have not been reached yet to agreed definition for M-learning; which indicates that m-learning is still in an evolving phase $[9,10]$. For the purpose of this study, I will follow Ally's (2009) definition of m-learning which describes m-learning as "The process of using a mobile device to access and study learning materials to communicate with fellow students, instructors or institution" $[11,12]$.

Moreover, this study will focus on the factors that affect on using of mobile device in learning in higher education students by explore the system factors, based on Technology Acceptance Model (TAM) was proposed by Davis.

\section{PROBLEM STATEMENT}

Mobile learning (M-learning) is a new type of learning mode which based on the use of mobile devices such as Personal Digital Assistants (PDAs), mobile/smart phones, notebooks or Tablet PCs [13]; to access educational information, resources and services such as course material, engage with the course activities, communication and feedback, useful papers or articles [14], newsletters, m-Learning events, and interact with the instructor and classmates [15].

M-learning is considered as an extension of E-learning but Mlearning [16] is not just e-learning with mobile devices; the information can be accessed anywhere, anytime, by anyone [17] with a proper authentication. Central to the e-learning and m-learning is the Learning Management System (LMS) [18] which make it possible to manage the course contents and organization of teaching. According to [19] there are challenges in the transition from E-Learning to M-Learning; one of the big challenges is the main difference between eLearning and m-Learning in the technologies used for educational content provided. However, LMS are not suitable for the mobile devices due to the limited viewing screen unit [20].These hinder the student's acceptance to use mobile devices as a tool to access the learning materials.

Finally, [9] "Identifying motivating factors for m-learning in developing countries is needed". The mobile learning at Jordan Universities is still at an early stage and limited adoption it. Students are the centre of the educational process [21]. So it is necessary to identify their attitudes towards using mobile phones in education rather than actual use

As a result, the purposes of this study will focus only on the quality factors for LMS that influence the acceptance of Mlearning; system quality (SQ) and information quality (IQ) were often used in the evaluation of system.

\section{LITERATURE REVIEW}

\subsection{Technology Acceptance Model (TAM)}

Technology Acceptance Model (TAM) model is one of the most widely used in the field of information technology acceptance modeling which was developed by Davis. TAM consists of three key concepts that are, Perceived Usefulness, Perceived Ease of Use, and Attitude toward using, that has a direct influence on intention to use it. This model is shown in Fig. 1. 


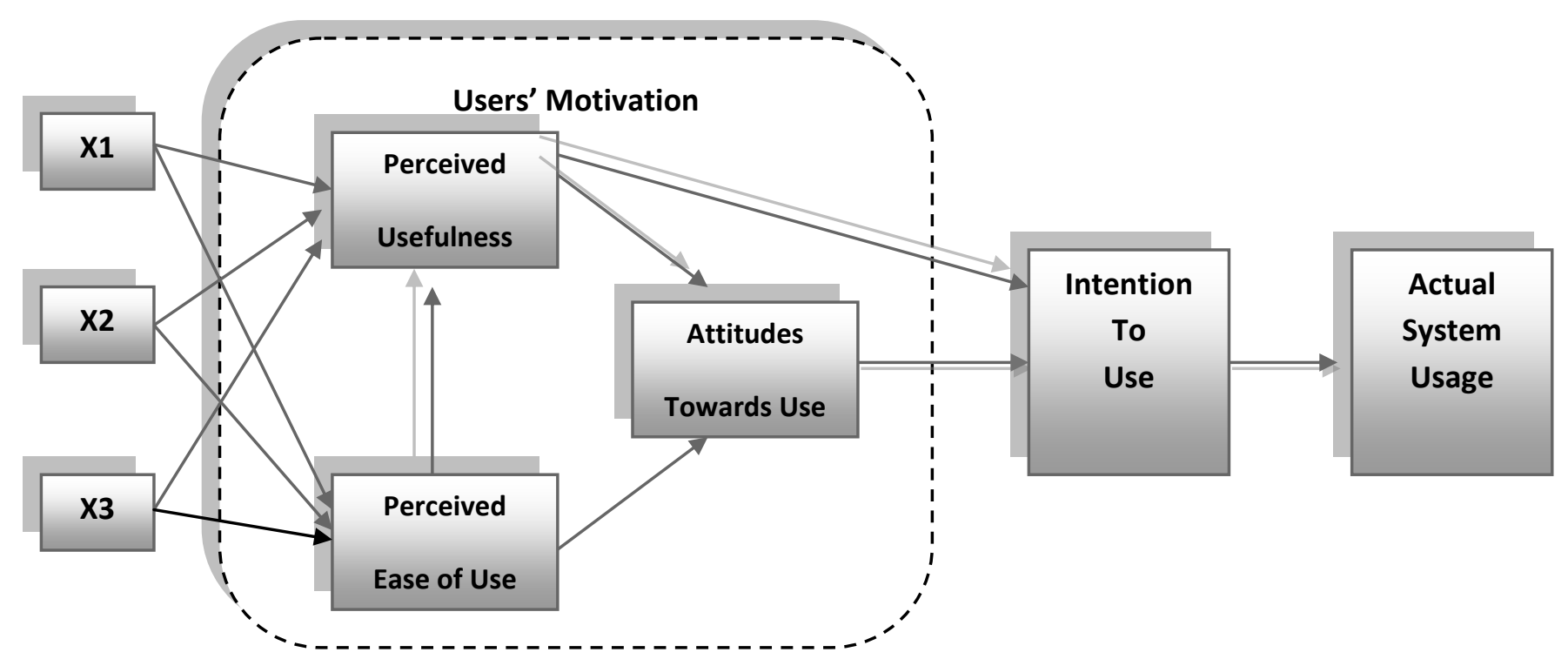

Fig 1: Technology acceptance model by Davis based on the original model [22]

All previous researches found with TAM model can efficiently expect the intention and adoption about information technology and systems. Moreover, the proposed research model will adopt Technology Acceptance Model of Davis (1989) as a theoretical model.

\subsection{Information system success model}

Identify the factors to determine the success of information systems was very hard. DeLone and McLean after reviewed the existing definitions of IS success and their related measures ;they have published paper with title "Information
Systems Success: The quest for the dependent variable" and proposed the first Information System Success Model (ISSM) to evaluate the success of information systems at an organizational level [23]. DeLone and McLean identify six dimensions for the success of information systems in an organization: system quality, information quality, use, user satisfaction, individual impact, and organizational impact as below in figure 2 .

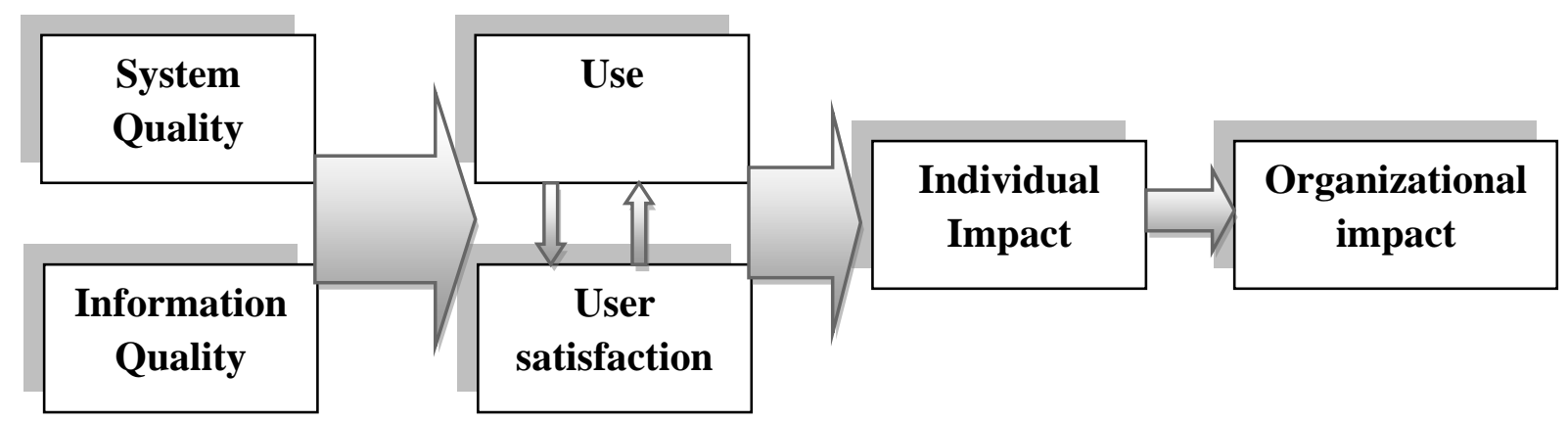

Fig 2: DeLone and McLean IS success model[23]

The model can be interpreted as follows: a system can be evaluated by information quality and system quality; these characteristics affect on use and user satisfaction. Use and user satisfaction affect on individual impact and finally organizational impact will be affected by organizational impact positively or negatively.

\subsubsection{System Quality (SQ)}

According to [23], one of the most considered dimensions of IS success is system quality. It refers to measures of the IS itself. System quality has been measured in many different ways in the IS literature such as convenience of access, flexibility of system, integration of system, response time [24]; reliability, response time, ease of use, ease of learning (Belardo et al. ,1982).

\subsubsection{Information Quality (IQ)}

According to [23], information quality refers to the quality of the information the system output. Information quality has been measured in many different ways. According to Bailey and Pearson (1983) measured information quality by asking if the output of the system is accurate, precise, current, timely, reliable, complete, concise, relevant, and in a preferred format.

Moreover, Information Quality and System Quality can be used to evaluate Information System (IS) successful; Mobile learning can be considered a type of information system. Consequently, System and information quality are very important elements of mobile learning system. Besides, in this research will investigate the effect of Information Quality and System Quality on m-learning as external variables on TAM model.

Finally, based on TAM model I will explore Quality Factors as external variables to find the effect of external variables on students' attitude to use M-learning for higher education students by using Perceived Ease of Use and Perceived 
Usefulness, as internal beliefs in TAM model, to propose a new model.

\section{RESEARCH FRAMEWORK AND HYPOTHESES}

The Technology Acceptance Model (TAM) will be adopted and guided the study. The model in figure (3) explains the causal relationships between Quality Factors (Information Quality and System Quality), Perceived Usefulness (PU), Perceived Ease of Use (PEOU), Attitude Toward (AT), and
Intension to Use (ITU). The proposed model based on TAM model will be described as follow: three particular beliefs Perceived Usefulness, Perceived Ease of Use, and Perceived Interaction will be determined by external variables Quality Factors. Based on the a below theoretical variables; this study presents research model and will discuss the relationships between all the factors that influence on M- learning for higher education students. The proposed model is illustrated in Fig. 3.

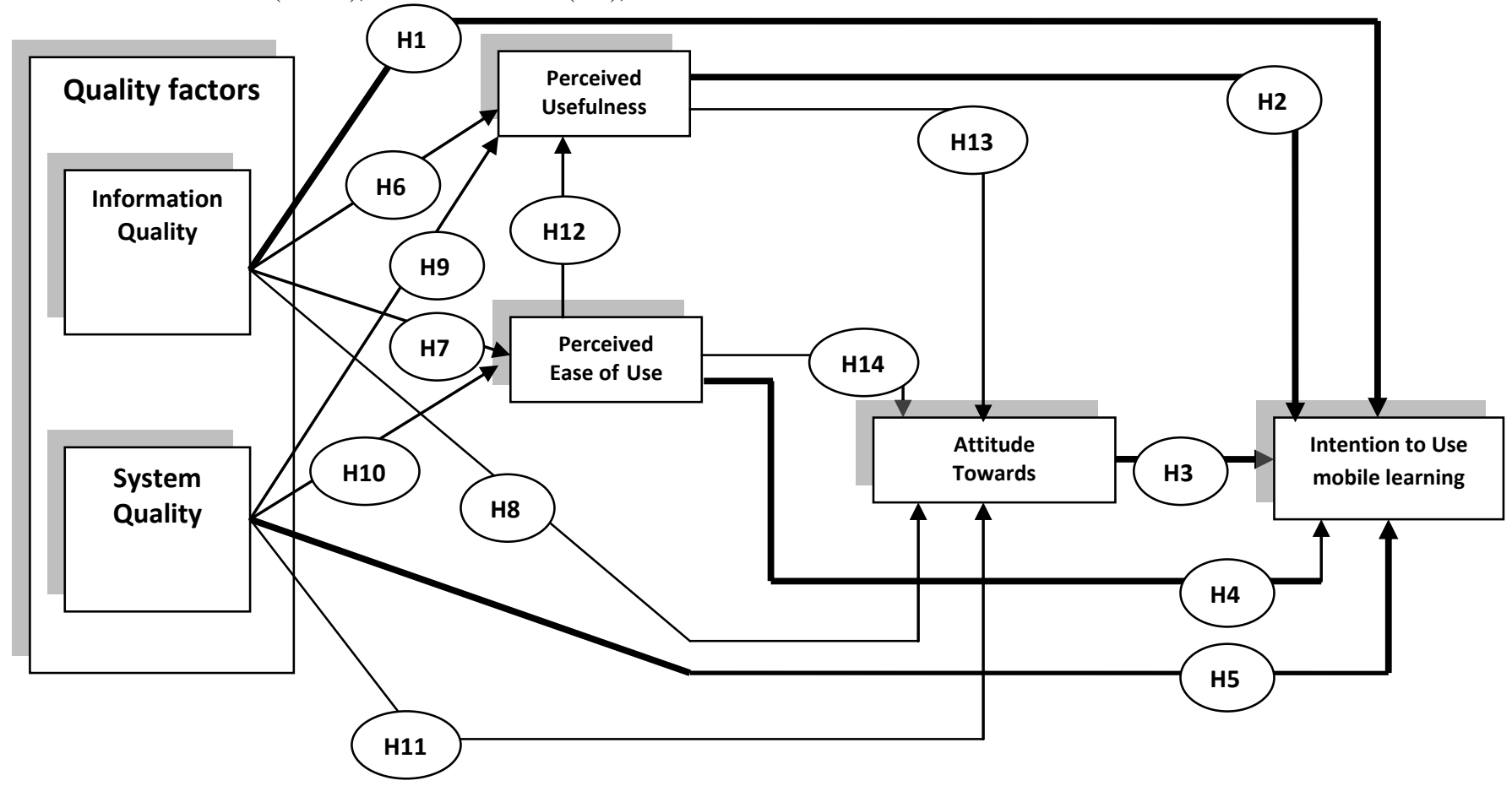

Fig 3 : Proposed model based on TAM And IS success model(Fig1 and Fig2)

\subsection{Research Hypotheses}

H1: Information Quality will have a positive influence on behavior intention to use.

$\mathrm{H} 2$ : System Quality will have a positive influence on behavior intention to use.

H3: Perceived Usefulness will have a positive influence on behavior intention to use.

H4: Perceived Ease of Use will have a positive influence on behavior intention to use.

H5: Attitude towards behavior will have a positive influence on behavior intention to use.

H6: Information Quality will have a positive influence on Perceived Usefulness.

H7: Information Quality will have a positive influence on Perceived Ease of Use.

H8: Information Quality will have a positive influence on Attitude towards behavior.

H9: System Quality will have a positive influence on Perceived Usefulness.

H10: System Quality will have a positive influence on Perceived Ease of Use.

H11: System Quality will have a positive influence on Attitude towards behavior.
H12: Perceived Usefulness will have a positive influence on Perceived Usefulness.

H13: Perceived Usefulness will have a positive influence on Attitude towards behavior.

H14: Perceived Ease of Use will have a positive influence on Attitude towards behavior.

\section{DATA ANALYSIS AND FINDINGS 5.1 Measurement properties for multi-item constructs}

A questionnaire was constructed; measuring the six core constructs of Information Quality (IQ) and System Quality (SQ), Perceived Usefulness (PU) and Perceived Ease of Use (PEOU), Attitude towards behavior (AT) and behavior intention to use (ITU). The constructs were measured by 21 statements. The statements were constructed from the original questionnaire items developed by Davis (1986) and DeLone and McLean

(1992). The statements were adapted to higher education students context from in private and public universities in Jordan. The statements measuring the core constructs are described in table 3 . The students were asked to rate their level of agreement to each statement on a five-point Likert scale ("I disagree completely" to "I agree completely"). The five core constructs of technology acceptance were hypothesized to influence students' rate of use of M-learning environments in a positive way. 
Table 1. Shows the main variables and their constructs with references

\begin{tabular}{|c|c|c|}
\hline Variables & $\begin{array}{c}\text { construct } \\
\text { Number }\end{array}$ & References \\
\hline IQ & 2 & {$[23]$} \\
\hline SQ & 2 & {$[23]$} \\
\hline PEOU & 2 & {$[22,25,26]$} \\
\hline P U & 3 & {$[22,25,26]$} \\
\hline AT & 3 & {$[22,25,26]$} \\
\hline ITU & 3 & {$[22,25,26]$} \\
\hline
\end{tabular}

Means and standard deviations of technology acceptance core constructs and correlation matrix for this study.The means of

each core construct ranged from 3.06 to 4.30 on a scale from 1 to 5 . The standard deviations of the constructs ranged from .95(Perceived Ease of Use (PEOU)) to 1.48 (behavior Intention To Use (ITU)).

Reliability of the instrument was ascertained using the Cronbach's coefficient alpha test. This tested for the internal consistency of the scales used to measure the variables. Table 3 displays the reliability indices/coefficients for all constructs used in the study .The Cronbach's $\alpha$ of every subscales range from .7853 to .8524 , which are above the acceptability value 0.7 .

Table 2. Measurement properties for multi-item constructs

\begin{tabular}{|c|c|c|c|c|}
\hline construct & $\begin{array}{c}\text { Standard } \\
\text { loading }\end{array}$ & Mean & $\begin{array}{l}\text { Standard } \\
\text { Deviation }\end{array}$ & $\begin{array}{l}\text { Cronbach's } \\
\text { Alpha }\end{array}$ \\
\hline $\begin{array}{l}\text { Information quality } \\
\begin{array}{ll}\text { 1- } & \text { Using mobile device in learning provides complete } \\
2- & \text { knowledge Data is accurate by using mobile device in learning }\end{array}\end{array}$ & .79 & $\begin{array}{l}3.60 \\
3.24\end{array}$ & $\begin{array}{l}1.14 \\
1.04\end{array}$ & .7526 \\
\hline $\begin{array}{l}\text { System Quality } \\
\begin{array}{ll}\text { 1- } & \text { M-earning system is convenience to use through Mobile } \\
\text { 2- } & \text { M-earning system is user friendly by mobile }\end{array}\end{array}$ & .78 & $\begin{array}{l}3.22 \\
3.36\end{array}$ & $\begin{array}{l}1.13 \\
1.11\end{array}$ & .7328 \\
\hline $\begin{array}{cl}\text { Perceived Use fullness (PU) } \\
1- & \text { Mobile learning would improve my learning performance } \\
2- & \text { Mobile learning would increase Academic productivity } \\
3- & \text { Mobile learning could make it easier to study course content }\end{array}$ & $\begin{array}{l}.88 \\
.90 \\
.86\end{array}$ & $\begin{array}{l}3.52 \\
3.25 \\
3.66\end{array}$ & $\begin{array}{l}1.07 \\
1.12 \\
1.05\end{array}$ & .8858 \\
\hline $\begin{array}{c}\text { Perceived Ease of Use (PEOU) } \\
\begin{array}{cl}1- & \text { I find mobile easy to use } \\
2- & \text { Learning how to use an E-mobile is easy for me }\end{array}\end{array}$ & $\begin{array}{l}.85 \\
.86\end{array}$ & $\begin{array}{l}4.08 \\
4.30\end{array}$ & $\begin{array}{l}.99 \\
.95\end{array}$ & .7036 \\
\hline $\begin{array}{cl}\text { Attitude } & \text { Towards behavior (AT) } \\
1- & \text { Studying through mobile learning is a good idea. } \\
2- & \text { Studying through mobile learning is a wise idea. } \\
3- & \text { I am positive toward mobile learning. }\end{array}$ & $\begin{array}{l}.88 \\
.92 \\
.86\end{array}$ & $\begin{array}{c}3.52 \\
4.012 \\
3.012\end{array}$ & $\begin{array}{l}1.06 \\
1.01 \\
1.03\end{array}$ & .7195 \\
\hline 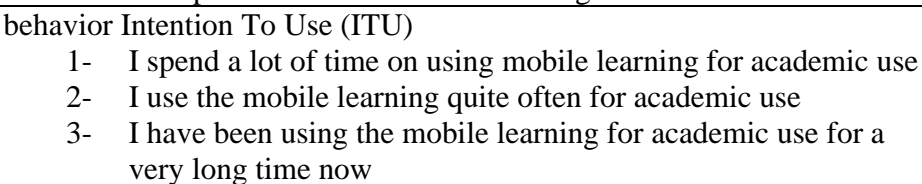 & $\begin{array}{l}.88 \\
.92 \\
.90\end{array}$ & $\begin{array}{l}3.25 \\
3.06 \\
3.22\end{array}$ & $\begin{array}{l}1.48 \\
1.43 \\
1.46\end{array}$ & .8982 \\
\hline
\end{tabular}

\subsection{Correlation Analysis among Variables}

Table: 3 describe correlation analysis among variables. There are six pairs of variables were correlated at $99 \%$ significant level. They are: Information Quality (IQ) and System Quality (SQ), Perceived Usefulness (PU) and Perceived Ease of Use (PEOU), Attitude towards behavior (AT) and behavior intention to use (ITU). This provides evidence for both discriminate and convergence validity.

Table (4) shows that (constructs), all the correlations in were below 0.85 , which doesn't indicate a poor discriminate validity in Structural Equation Model (SEM) [22]. The results obtained for these tests were satisfactory, indicating that the scales used in the measurement model are reliable.

Table 3. META-Analytic correlation values

\begin{tabular}{|c|llllll|}
\hline Construct & IQ & SQ & PEOU & PU & AT & ITU \\
\hline IQ & - & & & & & \\
\hline SQ & .35 & & & & & \\
\hline PEOU & 048 & .55 & & & & \\
\hline PU & .49 & .48 & .75 & & & \\
\hline AT & 0.34 & .39 & .50 & .51 & & \\
\hline ITU & 0.32 & .32 & .49 & .52 & .34 & \\
\hline
\end{tabular}




\subsection{Hypotheses, Standardized Path Coefficients and t-value (test Hypotheses)}

This study proposes that Information Quality by students in regard to mobile learning as the most important antecedent to their Intention and Attitude To Use of mobile technologies for learning (H1: IQ $\rightarrow$ ITU : .353, H8: IQ $\rightarrow$ AT: .231).These results found System Quality as the less important factor to their Intention and Attitude to use mobile device in learning process (H2: SQ $\rightarrow$ ITU: .147, H:11 SQ $\rightarrow$ AT: .146)
This study proposed that both Perceived Usefulness (PU) and Perceived Ease of Use (PEOU) have an effect on mobile phone users' behavior intention in Mobile Learning (H3: PU $\rightarrow$ ITU: .155, H4: PEOU $\rightarrow$ ITU: .187). Finally, as given in table $1(\mathrm{PU} \rightarrow$ ITU: .155, PEOU $\rightarrow$ ITU: .187, AT $\rightarrow$ ITU: .265 , IQ $\rightarrow$ PU: .632, IQ $\rightarrow$ PEOU: .200, SQ $\rightarrow$ PU: .245, SQ $\rightarrow$ PEOU: .109 , PEOU $\rightarrow$ PU, PU $\rightarrow$ AT: .149 , PEOU $\rightarrow$ AT: .478).Hence,H3,H4,H5,H6,H7,H9,H10,H12,H13 and $\mathrm{H} 14$ are accepted. As shown in Table 4.

Table 4. Hypotheses, Standardized Path Coefficients and t-value

\begin{tabular}{|l|l|l|l|l|}
\hline hypothesis & Path & $\begin{array}{l}\text { Standardized } \\
\text { Path Coefficient }\end{array}$ & t-value & $\begin{array}{l}\text { Hypothesis } \\
\text { Verified? }\end{array}$ \\
\hline H1 & IQ $\rightarrow$ ITU & .353 & $(7.246)^{*}$ & yes \\
\hline H2 & SQ $\rightarrow$ ITU & .147 & $(3.75)^{* *}$ & yes \\
\hline H3 & PU $\rightarrow$ ITU & .155 & $(3.90)^{* *}$ & yes \\
\hline H4 & PEOU $\rightarrow$ ITU & .187 & $(3.46)^{* *}$ & yes \\
\hline H5 & AT $\rightarrow$ ITU & .265 & $(4.50)^{* *}$ & yes \\
\hline H6 & IQ $\rightarrow$ PU & .632 & $(7.203)^{* *}$ & yes \\
\hline H7 & IQ $\rightarrow$ PEOU & .200 & $(6.212)^{* *}$ & yes \\
\hline H8 & IQ $\rightarrow$ AT & .231 & $(4.321)^{* *}$ & yes \\
\hline H9 & SQ $\rightarrow$ PU & .245 & $(4.413)^{* *}$ & yes \\
\hline H10 & SQ $\rightarrow$ PEOU & .109 & $(3.77)^{* *}$ & yes \\
\hline H11 & SQ $\rightarrow$ AT & .146 & $(2.74)^{* *}$ & yes \\
\hline H12 & PEOU $\rightarrow$ PU & .148 & $(4.75)^{* *}$ & yes \\
\hline H13 & & & $(2.76)^{* *}$ & yes \\
\hline H14 & PU $\rightarrow$ AT & .149 & .478 & yes \\
\hline & PEOU $\rightarrow$ AT & & & \\
\hline
\end{tabular}

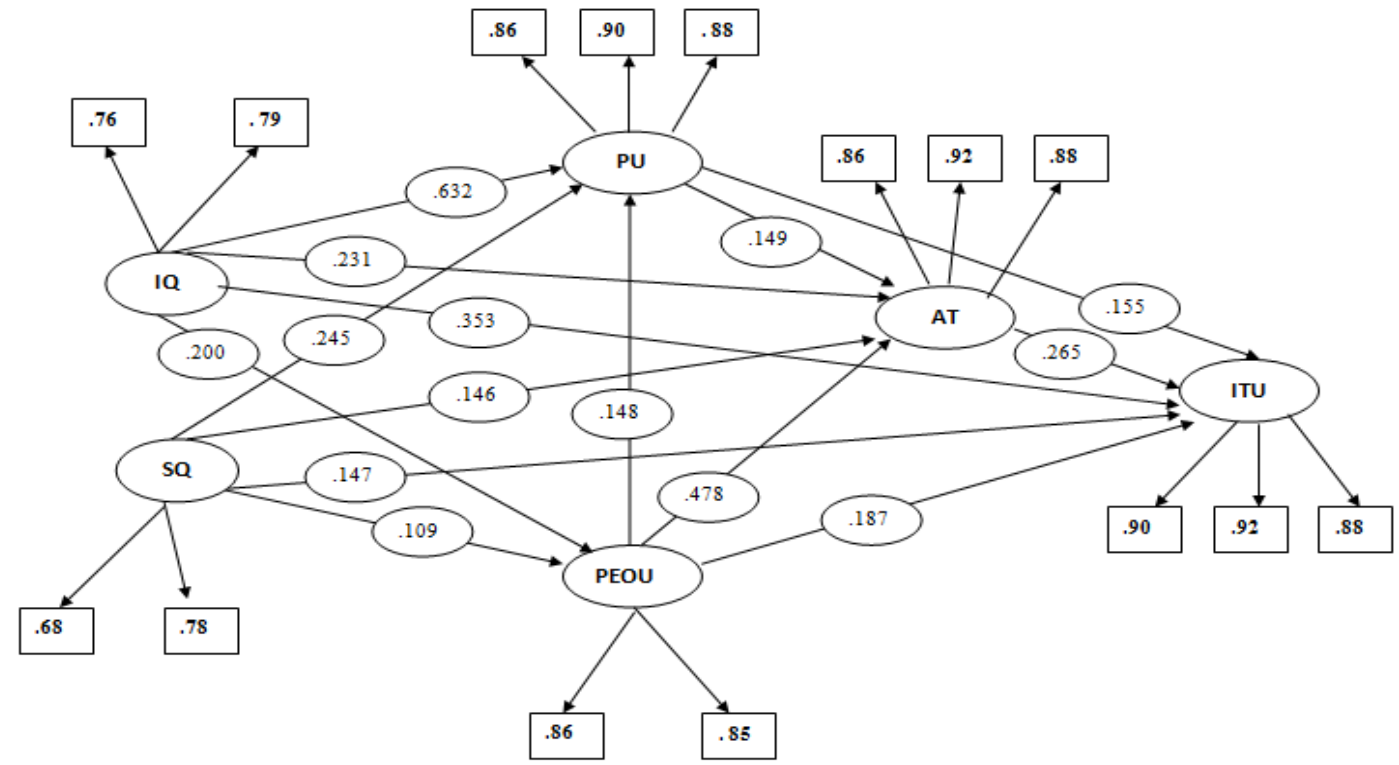

Fig 4: shows the path coefficients estimated by AMOS. 


\section{CONCLUSION}

This study integrates Technology Acceptance Model and the Information Systems Success Model to justify the student's intension to use mobile device as a learning tool. This study makes significant contributions to both academia and developers; it finds Information Quality by students in regard to mobile learning as the most important variable to their Intention and Attitude to Use of mobile technologies for learning. Future studies should further develop the proposed model and verify the proposed model with broader samples.

\section{REFERENCES}

[1] P. Donnelly, J. Benson, and P. Kirk, How to Succeed at E-learning vol. 37: Wiley-Blackwell, 2012.

[2] J. Coultas, R. Luckin, and B. du Boulay, "How compelling is the evidence for the effectiveness of eLearning in the post-16 sector?," Available at:(Accessed 25 May 2007), 2003

[3] K. Jairak, P. Praneetpolgrang, and K. Mekhabunchakij, "An acceptance of mobile learning for higher education students in Thailand," in Sixth International Conference on eLearning for Knowledge-Based Society, Thailand, 2009, pp. 17-18.

[4] K. Peters, "m-Learning: Positioning educators for a mobile, connected future," Mobile learning, p. 113, 2009.

[5] M. Paige, "Sams teach tourself jQuery mobile in 24 hours by Phil Dutson," ACM SIGSOFT Software Engineering Notes, vol. 38, pp. 56-57, 2013.

[6] J. M. Mateo-Sanz, "Distributed Architecture with Double-Phase Microaggregation for the Private Sharing of Biomedical Data in Mobile Health," 2013.

[7] J. Traxler, "Mobile Learning: Shaping the Frontiers of Learning Technologies in Global Context," in Reshaping Learning: Springer, 2013, pp. 237-251.

[8] W. P. Mtega, R. Bernard, A. C. Msungu, and R. Sanare, "Using Mobile Phones for Teaching and Learning Purposes in Higher Learning Institutions: the Case of Sokoine University of Agriculture in Tanzania," UbuntuNet-Connect 2012 Promoting regional Research and Education Collaboration, p. 118, 2012.

[9] S. Iqbal and I. A. Qureshi, "M-learning adoption: A perspective from a developing country," The International Review of Research in Open and Distance Learning, vol. 13, pp. 147-164, 2012.

[10] H. Peng, Y. J. Su, C. Chou, and C. C. Tsai, "Ubiquitous knowledge construction: Mobile learning re- defined and a conceptual framework," Innovations in Education and Teaching International, vol. 46, pp. 171-183, 2009.

[11] M. Ally, Mobile learning: Transforming the delivery of education and training: Athabasca University Press, 2009.

[12] R. Ali and V. Irvine, "Current m-learning research: A review of key literature," in World Conference on E-
Learning in Corporate, Government, Healthcare, and Higher Education, 2009, pp. 2353-2359.

[13] A. Anani, "M-learning in review: Technology, standard and evaluation," Journal of Communication and Computer, vol. 5, pp. 1-6, 2008.

[14] E. Al-Masri and Q. H. Mahmoud, "MLDF: Discovering Mobile Learning Content using Mobile Devices," 2012.

[15] L. Mockus, H. Dawson, S. Edel-Malizia, D. Shaffer, J. An, and A. Swaggerty, "The impact of mobile access on motivation: Distance education student perceptions," World Campus Learning Design, 2011.

[16] P. Nedungadi and R. Raman, "A new approach to personalization: integrating e-learning and m-learning," Educational Technology Research and Development, vol. 60, pp. 659-678, 2012.

[17] Y. Rogers, H. Sharp, and J. Preece, Interaction design: beyond human-computer interaction: Wiley, 2011.

[18] G. Yang, D. Wen, N.-S. Chen, and E. Sutinen, "Personalized Text Content Summarizer for Mobile Learning: An Automatic Text Summarization System with Relevance Based Language Model," in Technology for Education (T4E), 2012 IEEE Fourth International Conference on, 2012, pp. 90-97.

[19] G. Trajkovski, "Transitioning from e-Learning to mLearning: Present Issues and Future Challenges," 2013.

[20] M. Simkova, H. Tomaskova, and Z. Nemcova, "Mobile Education in Tools," Procedia-Social and Behavioral Sciences, vol. 47, pp. 10-13, 2012.

[21] K. Y. Qudah, J. A. Hussain, and R. Al Matari, "Students' Attitudes in Colleges of Education at the Jordanian Universities towards Mobile Phone Usage in University Education," iJIM, vol. 7, pp. 19-28, 2013.

[22] F. D. Davis, R. P. Bagozzi, and P. R. Warshaw, "User acceptance of computer technology: a comparison of two theoretical models," Management science, vol. 35, pp. 982-1003, 1989.

[23] W. H. DeLone and E. R. McLean, "Information systems success: the quest for the dependent variable," Information systems research, vol. 3, pp. 60-95, 1992.

[24] J. E. Bailey and S. W. Pearson, "Development of a tool for measuring and analyzing computer user satisfaction," Management science, vol. 29, pp. 530-545, 1983.

[25] V. Venkatesh, M. G. Morris, G. B. Davis, and F. D. Davis, "User acceptance of information technology: Toward a unified view," MIS quarterly, pp. 425-478, 2003.

[26] F. D. Davis, "User acceptance of information technology: system characteristics, user perceptions and behavioral impacts," International journal of man-machine studies, vol. 38, pp. 475-487, 1993. 